И в таком формате данный документ также проходит все процедуры оформления, как и согласно законодательству. Где почти невозможно сделать подделку подписи в электронном коносаменте, что очень важно с точки зрения безопасности. В связи с переходом коносамента в электронный формат и разделились мнения за и против. Одни считают, что при введении коносамента в цифровой вид это минимизирует время передачи документа, так как высокая скорость передачи данных во всемирной сети интернет позволит совершить операцию в очень сжатые сроки без возможности внести постороннему лицу изменения в документ, нежели доставка документа в бумажной форме, которая произойдет спустя длительное время. Законодательство тоже вносит свои коррективы на этот счет.

Особенность электронного коносамента - это безопасность. Так как, подписи невозможно подделать и легко отслеживается товарораспределительный документ.[3,стр.204] При глобализации в современном мире мировой рынок не стоит на месте и тем самым для укрепления международных отношений требуется модернизация и в области документооборота, что ускорит процесс налаживания договорных отношений и придаст ценность такому обороту. Слияние России в международную транспортную систему приведет к обмену товарооборотом, расширению вложения инвестиций, что повысит экономический уровень страны. Следовательно, коносамент как бумажный документ уходит в прошлое по мере развития электронного документооборота. Но, необходимо учитывать незавершенность в правовом аспекте данного вида документа. Также, цифровизация для бизнеса и грузовладельцев - это доступный способ к сервису перевозок. Прозрачнее становится процесс заказа и его отслеживание исполнения. Также необходимо отменить, что при правовом регулирования в России согласно ст. 142 ГК РФ коносамент является ценной бумагой, а электронный коносамент соответственно бездокументарной ценной бумагой, к которой применимы требования ст. 149 ГК РФ. Таким образом, цифровизация в документообороте вносит необратимые на наш взгляд поправки для упрощения ведения дел удаленно.

$$
* * *
$$

1. Panagiota, K. Electronic bills of lading: Legal obstacles and solutions, Hertfordshire, 2004. Law Journal, 2, 45-54. URL: https://www.herts.ac.uk/_data/assets/pdf_file/0008/38636/HLJ_V2I1_Pan agiota.pdf (дата обращения 19.04.2019г.);

2. Баскаков П .В., Матюшин Л .Н ., 2015, Интеграция России в международную транспортную систему (функциональный аспект)

3. Оселедец Д.А. Правовое регулирование использования электронного документооборота в морской перевозке грузов по коносаменту // Российское предпринимательство. - 2014. - Том 15. - № 20. C. 204-214.

\title{
Осипова А.С. \\ Вопросы о разграничении присвоения найденного чужого имущества и кражи
}

ФГКОУ ВО «Университет прокуратуры Российской Федерации»

(Россия, Москва)

doi: $10.18411 / \mathrm{j}-07-2021-96$

\section{Аннотация}

Статья раскрывает проблему, которая возникла в судебно-следственной практике при рассмотрении случаев, когда имело место быть присвоение движимого имущества, то есть вещи, потерянной собственником либо другим владельцем или вещи, оставленной без присмотра. Уполномоченные сотрудники правоохранительных органов и судьи дают различные юридические оценки (квалификацию) подобных действий граждан: или присвоение находки, или это кража чужого имущества. 
Возникает необходимость в разграничении гражданско-правового поступка и преступления. Выделяются определенные объективные признаки кражи, а также уточняются определенные содержательные и сущностные аспекты «тайности» хищения. Автором была предпринята попытка найти путь для разрешения возникшей проблемы.

Ключевые слова: изъятие, кража, присвоение, находка, чужое имущество, собственность, приобретение права собственности, имущественные преступления.

\section{Abstract}

The article reveals a problem that has arisen in the judicial and investigative practice when considering cases when there was an appropriation of movable property, that is, a thing lost by the owner or another owner or a thing left unattended. Authorized law enforcement officers and judges give various legal assessments (qualifications) of such actions of citizens: either the appropriation of a find or it is the theft of someone else's property. There is a need to distinguish between a civil act and a crime. Certain objective signs of theft are highlighted, and certain substantive and essential aspects of the "secrecy" of theft are specified. The author made an attempt to find a way to resolve the problem.

Keywords: withdrawal, theft, appropriation, discovery, other people's property, property, acquisition of ownership, property crimes.

Круг законных свобод, прав и интересов человека и гражданина достаточно разнообразен и соответствует установленным общепризнанным мировым стандартам. К их числу относится и право собственности, которое выступает в качестве одного из юридических и экономических основ конституционного строя Российской Федерации. Статьей 8 Конституции Российской Федерации провозглашается признание и защита в равной степени частной, муниципальной и государственной, а также других форм собственности [1]. Из этой статьи, также вытекает равенство всех участников частноправовых имущественных отношений перед законом.

Нормы уголовного законодательства практически повсеместно трактуются таким образом, что преступления, направленные против собственности, считаются одним из наиболее распространенных совершаемых общественно опасных деяний. В настоящее время, хищения занимают ключевое место в общей преступности Российской Федерации, за счет чего и определяют ее количественную структуру [6].

Охрана собственности выступает в качестве одного из важнейших аспектов установленного действующего законодательства, в том числе норм уголовного права.

Одной из первостепенных проблем в данной области является разграничение понятия кражи, рассматриваемого как уголовно наказуемого деяния, и присвоения найденного имущества, то есть правомерного завладения чужим имуществом. Главный вопрос, возникающий в квалификации действий лица в подобной ситуации: является ли имущество чужим в том случае, когда собственник не отказывается от него по собственной воле, но при этом самостоятельно утрачивает право владения, например, забывает либо теряет свое имущество в общественном месте, то есть право владения имуществом никому добровольно собственником не передавалось.

По смыслу закона, под кражей подразумевается тайное хищение чужого имущества, где содержание преступных действий не только объективно, но и субъективно, выражается в том, что вор стремится избежать любого контакта с собственником, то есть с непосредственным владельцем имущества или с другими лицами, которые могут каким-либо образом воспрепятствовать преступлению либо оказать содействие в изобличении преступника [4].

К основным особенностям, которые могут четко охарактеризовать признаки кражи, относятся такие обстоятельства: 
1. виновное лицо не имеет никаких юридических правомочий по отношению похищаемого имущества, то есть:

- завладевая каким-либо чужим имуществом, лицо, совершившее преступление, осознает, что оно не имеет ни предполагаемого, ни действительного права на имущество, поэтому похищает его вопреки воле собственника данного имущества;

2. виновным лицом используется ненасильственный способ завладения чужим имуществом, то есть:

- кража совершается в обход воли и сознания потерпевшего лица;

3. виновное лицо, в процессе совершения хищения, стремится быть максимально незамеченным либо скрытыми могут быть его действия.

Таким образом, можно сделать вывод, что в том случае, когда лицо, совершающее преступление понимает, что имущество ему не принадлежит, а также осознает противоправность своих действий и при этом желает незаконно завладеть чужим имуществом, то действия лица должны квалифицироваться как кража, то есть, как тайное хищение имущества в корыстных целях.

Присвоение найденного чужого имущества - это невыполнение лицом своей непосредственной правовой обязанности по передаче найденного имущества по принадлежности. С данной точки зрения присвоение найденного имущества выступает в качестве безвозмездного обращения в свою пользу или в пользу иных лиц заведомо чужого имущества за счет его удержания.

В общем понимании, находка объединяется с остальными предметами в единое понятие «бесхозяйные вещи». Данное понятие регламентировано в ст.255 ГК РФ и трактуется как вещи, которые не имеют собственника либо те вещи, собственник которых неизвестен, а также вещи, от права собственности на которые собственник отказался [2]. На основании этого, действия лица, которое обнаружило находку, должны различаться в зависимости от того, известен ли хозяин утерянной вещи или нет. Знание о том, кому принадлежит данная утраченная вещь, прямо указывает на осведомленность лица о ее владельце и о его правах на данное имущество, а также на отсутствие у него права на приобретение этой находки и обращение найденного имущества в свою собственность.

Положения о находке, в силу которого нашедшее потерянную вещь лицо обязуется незамедлительно уведомить об этом лицо, которое ее потеряло, не могут распространяться на такие случаи, когда собственник утерянной вещи известен. В такого рода ситуациях необходимо принимать во внимание тот факт, что понятие «находка», прежде всего, основывается на случайности этого события. Вознаграждение нашедшему лицу предполагает собой определенные усилия, которые были приложены человеком для того, чтобы отыскать вещь и ее собственника. В связи с этим, в том случае, если вещи были оставлены, например, в номерах гостиниц, мастерских и тому подобных помещениях, когда собственник известен, они не могут являться находкой. Возврат подобных вещей собственнику - это прямая обязанность соответствующих заведений и их руководства. Присвоение подобных вещей должно образовывать хищение чужого имущества, то есть кражу, а не присвоение находки либо неосновательное обогащение. Находка, в свою очередь, требует неизвестности собственника. Таким образом, присвоение находки по своей сути представляет конкретный юридический поступок, то есть правомерное действие определенного субъекта, с которым законодательство связывает соответствующие юридические последствия, вне зависимости от того, была ли у субъекта цель для достижения какоголибо правового результата [5].

Таким образом, рассмотрев кражу и присвоение найденного чужого имущества, для квалификации присвоения чужого имущества по признакам состава преступления, которое предусмотрено ст. 158 УК РФ, необходим факт осознания у лица, которое 
присваивает чужую вещь, конкретного человека и возможность возврата данной вещи ее собственнику [3]. Как кража должны быть квалифицированы действия такого лица, которому достоверно известен факт принадлежности, то есть, кому именно принадлежит имущество, или лицо, совершающее преступление должно знать, что собственник может вернуться за своей забытой вещью. В случае утраты вещи, ее законный владелец не может точно знать о месте ее нахождения, а при оставлении своей вещи это место ему достоверно известно. Обстоятельства утраты либо оставления имущества должны быть определены исходя из конкретных признаков внешней обстановки обретения и утраты имущества: как, каким образом и где именно находилась вещь.

Более того, важно учитывать конкретные обстоятельства каждого дела. В частности, к таким обстоятельствам можно отнести место обнаружения имущества виновным лицом, свойства и характеристики данного имущества, условия при которых данное имущество было обнаружено. При таких обстоятельствах, когда имущество находится во владении потерпевшего лица, например, в его жилплощади либо в какомто другом месте, которое выступает в качестве обычного либо надлежащего местонахождения имущества или вещи, завладение таким имуществом либо подобной вещью образует хищение. Когда виновное лицо незаконным образом завладевает имуществом в присутствии потерпевшего лица, например, если человек только что обронил либо выронил какую-либо вещь из кармана, или преступное лицо присваивает имущество, по забывчивости либо по ряду других причин, оставленное в каком-либо месте имущество, его только что ушедшим собственником, то в действиях данного лица также могут просматриваться признаки хищения чужого имущества. В таких ситуациях имущество остается во владении потерпевшего лица, который после того, как обнаружил свою потерю, имеет возможность отыскать ее. Завладение имуществом в данных условиях, зачастую, имеет своим результатом лишение потерпевшего лица реальной возможности вернуть оставленное либо утраченное им имущество. То есть, имущество, которое было временно оставлено собственником без присмотра, будет считаться находящимся в его владении, а завладение данным имуществом другим лицом будет квалифицировано как кража.

Базовый вопрос в проблематике разграничения двух рассматриваемых понятий заключается в том, является ли имущество чужим в случае, при котором собственник не отказывается от своего титула, но при этом сам утратил господство над своим имуществом либо вещью и никому не вверяет ее [7].

Таким образом, основополагающими критериями, которыми нужно руководствоваться в процессе решения вопроса о разграничении присвоения найденного чужого имущества и кражи, выступают следующие обстоятельства:

1. место утраты и место обнаружения утраченного имущества;

2. наличие каких-либо идентифицирующих признаков, которые могут позволить без особого труда установить собственника имущества;

3. знание либо, наоборот, незнание нашедшим лицом, владельца утраченного имущества;

4. свойство имущества, то есть было ли оно забыто, оставлено или утрачено, относительно его принадлежности собственнику.

$$
* * *
$$

1. Конституция Российской Федерации (принята всенародным голосованием 12 декабря 1993 г.)// "Российская газета" от 4 июля 2020 г. N 144

2. Часть первая Гражданского кодекса Российской Федерации от 30 ноября 1994 г. N 51-Ф3// Собрание законодательства Российской Федерации от 5 декабря 1994 г. N 32 ст. 3301

3. Уголовный кодекс Российской Федерации от 13 июня 1996 г. N 63-Ф3// Собрании законодательства Российской Федерации от 17 июня 1996 г. N 25 ст. 2954 
4. Зубцов, А.А. Разграничение норм о находке и тайном хищении чужого имущества: проблемы теории и практики// Уголовное право. - 2019 г. - №3. - 25-31 с.

5. Лазарев, А.М. Вопросы разграничения кражи и присвоения найденного чужого имущества// Вестник ВГАВТ. - 2017 г. - №53. - 227-233 с.

6. Филиппова, Л. А. Квалификация хищений / Л. А. Филиппова. - Текст: непосредственный // Молодой ученый. — 2019 г. — № 29 (267). — 121-123 с.

7. Хилюта, В.В. Кража и присвоение найденного: проблемы соотношения и выявления разграничительных признаков// Журнал российского права. - 2019 г. - №2. - 132-143 с.

\section{Панова Е.И. \\ Правовая и процессуальная активность, как виды юридической активности}

Российский государственный университет правосудия (Россия, Симферополь)

doi: $10.18411 / \mathrm{j}-07-2021-97$

\section{Аннотация}

В данном исследовании произведен анализ понятия правовая активность и процессуальная активность, обусловлена их роль в практической деятельности адвоката.

Ключевые слова: правовая активность, процессуальная активность, правовое государство, социально-правовая активность, юридическая деятельность, адвокат, представитель, защитник.

\section{Abstract}

This study analyzes the concepts of legal activity and procedural activity, and determines their role in the practice of a lawyer.

Keywords: legal activity, procedural activity, legal state, social and legal activity, legal activity, lawyer, representative, defender.

Введение. Основная цель судопроизводства - защита прав и свобод человека и гражданина (истца, ответчика, третьих лиц, потерпевшего, обвиняемого и т.д). Достижение этой цели возможно только при активных действиях граждан, чьи права затрагивает конкретный процесс. Актуальным является вопрос, насколько действующее законодательство предоставляет возможность физическим лица, участникам процессуальных правоотношений, отстаивать собственные права, определяя должное и возможное поведение.

Данные аспекты обусловили актуальность современного исследования роли правовой и процессуальной активности индивида в современном мире.

Цель исследования - изучить правовую и процессуальную активность, как виды юридической активности граждан в Российской Федерации.

Изложение основного материала. Исследуя научный материал по теме данного исследования, мы приходим к выводу, о том, что вопросы правовой активности подверглись достаточно тщательному анализу в литературе. Кроме того, правовая активность индивида может рассматриваться в узком и широком смысле. В широком смысле правовую активность индивида можно рассматривать как любую деятельность, которая так или иначе юридически обоснована, связана с участием в установленных нормами правах общественных отношений. В узком смысле правовая активность связана с юридическими действиями, связанными с конкретным лицом, конкретным субъектом права.

А.М. Лесникова данный термин понимает, как своего рода правовую деятельность, которая проявляется посредством реальных правовых действий, и которой присуща совместная оценка правоохранительными органами. В противном 